\title{
Outdoor Education: An Alternative Approach in Teaching and Learning Science
}

\author{
Tuan Mastura Tuan Soh ${ }^{1} \&$ Tamby Subahan Mohd Meerah ${ }^{1}$ \\ ${ }^{1}$ Faculty of Education, Universiti Kebangsaan Malaysia, Selangor, Malaysia \\ Correspondence: Tuan Mastura Tuan Soh, Faculty of Education, Universiti Kebangsaan Malaysia, 43600 Bangi, \\ Selangor, Malaysia. Tel: 60-13-700-0337. E-mail: tuanmastura@ukm.my
}

Received: August 16, 2013 Accepted: October 14, 2013 Online Published: November 28, 2013

doi:10.5539/ass.v9n16p1

URL: http://dx.doi.org/10.5539/ass.v9n16p1

\begin{abstract}
To understand fully and aware of children's science learning, one should look not only at learning that takes place in the kindergarten and primary school but also in learning that takes place outside the classroom. This paper aims to discuss outdoor education: an alternative approach in teaching and learning science in the Malaysian context. In this $21^{\text {st }}$ century, the exposure and experience in the field of science and technology are needed in nurturing interest among students who are involved in this field. The advantages of experience-based learning which includes hands-on activities and on-site learning should be empowered. Thus, informal and non-formal science learning plays an important role in assisting all levels of society, regardless of age in exploring science and technology. Informal and non-formal learning of science is a complement to formal learning and occur in a variety of different places through various channels, such as the entertainment media, television and film; science centres and museums; zoos and aquariums, botanical gardens, and etc. This paper discusses the concept of science learning outside the classroom; the non-formal and informal science learning which covers the institutions/organizations involved in the non-formal science learning in Malaysia; and the potential of non-formal science centre setting in complement with the formal science education setting. It is hoped that this paper will provide an insight towards science learning out of school in Malaysian context.
\end{abstract}

Keywords: experiential learning, formal learning, informal learning, non-formal learning, outdoor education

\section{Introduction}

In the $21^{\text {st }}$ century, Malaysia faces new challenges due to globalization, liberalization, internationalization and the development of information and communication technology (ICT) (Osman, Tuan Soh \& Arsad, 2010; Tuan Soh, Osman \& Arsad, 2012). Changes have occurred in the ways science educators and researchers view the learning that occur in, and emerges from, experiences in informal contexts such as museums, science centres, botanic gardens and aquarium. Prior to the 1980s, there was a search for evidence and a widespread lack of acceptance that "real learning" occurred in such contexts (Anderson, Thomas \& Ellenbogen, 2003). Therefore, it is important for the educational system to make parallel changes in order to fulfil its mission of the society, namely the preparation of students for the world beyond the classroom.

In Malaysia, science education in schools serves as the spirit to achieve the National Science Education Philosophy, although the Policy of 60:40 (Technical Science Stream: Arts) already exists in the education system since 1970 and still continuing until now. As stated in the report of the" strategy to achieve 60:40 policy of 60:40 Scientific/Technical: Arts by the Ministry of Education (MOE) of Malaysia, although after 42 years of this policy were introduced, the result has shown that this policy has not yet achieved its goal (Ministry of Education, 2012a). It is sad to report that an analysis of students pursuing science stream in these past 10 years showed that, Malaysia has never achieved or reached the ratio of 60:40. Not only the policy is remaining unachievable, even the interest of students towards science is also declining (BERNAMA, 2012; Lee \& Kamisah, 2013; Mohd Khaled, 2012). Nevertheless, this phenomenon occurs not only in Malaysia but also all around the world where there is a drop in the perception and interest of students in science. (BERNAMA, 2012; IEA, 2008; Fatin Aliah, Mohd Salleh, Mohammad Bilal \& Salmiza, 2012; Lee \& Kamisah, 2013; Mohd Khaled, 2012; PISA, 2009).

From an international view of comparison, the achievement of science in the Trends in International Mathematics and Science Study (TIMSS) also found an average decline where Malaysia obtained only an average score of 492 on TIMSS cycles in 1999, it rose slightly to 510 scores in 2003, however, it declined again 
to 471 scores in 2007 and further decreased to 462 in 2011 (International Association for the Evaluation of Educational Achievement (IEA), 2008; MOE, 2012,). In addition, a report by Programme for International Student Assessment (PISA, 2009) also stated Malaysia was ranked 57 out of 74 countries with below attainment. For Mathematics domain, the average score is 404 (international average $=458$; OECD average $=496$ ); whereas the average score for Science domain is 422 (international average $=463$; OECD average $=501$ ). PISA is an international study which aims to evaluate education systems worldwide by testing the skills and knowledge of 15-year-old students with real life skills that engage the lifelong learning process of mathematics, science and reading. As the PISA sees more skills that involve the ability to interpret, reflect and evaluate, Malaysian students were still weak in those skills that are important in real life. This is very disappointing and critical to be addressed.

Such circumstances and scenarios stated above would be an obstacle to the goal of producing globally competitive human capital and contribute towards the development of scientific and technological civilization. Therefore, various views have been put forward in an attempt to explain the phenomenon of students' declining interest in science. Among them were; i) the delivery effectiveness of science and technology education depending on the curriculum and assessment; ii) the quantity and quality of teachers; iii) facilities and efficiency of school management; and iv) support and encouragement from parents and the school. According to Kuenzi (2008), one approach to encourage science learning is through the use of informal educational channels. Whereas, Hofstein and Rosenfeld (1996) make an important recommendation that "future research in science education should focus on how to effectively blend informal and formal learning experiences in order to significantly enhance the learning of science" (p. 107).

Yet, in reality, there is still a boundary between informal and formal learning although Tight (1996) argues that learning is not limited to the formal setting of the school. In addition, Delamont (2002) also argues that educational research needs to leave the boundaries of the indoor classroom and look at the educational process within other settings, including informal learning. Studying the interactions that occur between pupils and teachers in a different environment, such as an outdoor centre, may shed more light on the learning processes that take place during outdoor activities, as the outdoors can provide opportunities that may not be available to the researcher in the indoor classroom (Stan, 2008). Therefore, this paper will discuss the concept and role of science learning outside the classroom, specifically informal and non-formal science learning in the Malaysian context.

\section{Concept of Science Learning Outside the Classroom}

Human beings learn science from a variety of sources, in a variety of settings, and for a variety of reasons. For the sake of simplicity, according to Hofstein and Rosenfeld (1996), we assume that the two complementary contexts for science learning are formal and informal learning.

Formal education according to Dib (1988) is the education that corresponds to a systematic, organized education model, structured and administered according to a given set of laws and norms, presenting a rather rigid curriculum as regards objectives, content and methodology. Formal education institutions are administratively, physically and curricularly organized and require minimum students' classroom attendance. There is a program that teachers and students alike must observe, involving intermediate and final assessments in order to advance students to the next learning stage. Assessments are made on a general basis, for administrative purposes and are infrequently used to improve the education process.

Whereas, the notions of non-formal and informal education came to prominence during the 1960s and 1970s in international discussions on education, at the same time as lifelong education first became fashionable. (Eshach, 2006) argues that dividing out-of-school learning into informal and non-formal categories help to achieve better understanding of the characteristics of out-of-school learning. To gain a better understanding about the science learning outside the classroom, this section will present a summary about the informal and non-formal learning.

\subsection{Non-formal Learning}

As seen, formal education has a well-defined set of features and generally cannot disguise its aloofness from the real needs of the students and of the community. To distinguish between formal and non-formal education, whenever one or more of the features defined in formal education is absent, we may safely state that the educational process has acquired non-formal features. Eshach (2006) defines the non-formal learning as learning that "occurs in a planned but in highly adaptable manner in institutions, organizations and situations beyond the spheres of formal or informal education. The author stated that non-formal learning of science occurs at places we visit occasionally such as science centres/museums, botanical garden, zoo, aquarium, planetarium, industry, interactive exhibit etc. It shares the characteristic of being mediated with formal education, but the motivation 
for learning may be wholly intrinsic to the learner.

Besides, the Commonwealth Secretariat (1979) defined the concept of non-formal education as "any organised learning activity outside the structure of the formal education system that is consciously aimed at meeting specific learning needs of particular subgroups in the community - be it children, youth or adult." Thus, non-formal learning refers to any organized and systematic educational activity, carried on outside the framework of the formal system, to provide selected types of learning to particular subgroups in the population; adults as well as children (Tight, 1996) and sometimes it is more stressed on skills (Colleta et al., 1982).

\subsection{Informal Learning}

Informal education is generally considered to be a kind of learning which continues in every part and phase of an individual's life and usually occurs outside a formal educational establishment. Educators in informal education focus on empirical learning which enables people to discover different experiences and learn from experiences (Best, 2007). It is also described as the learning process taking place out of classroom environment; such learning can occur through an educational television program, radio, newspapers, magazines, internet, sport centres, during a travel or a visit to a museum, science centres, art gallery, historic site or zoo (Davies, 1997; Hannu, 1993; Kelly, 2000; Martin, 2004; Pedretti, 2004). Informal environments encourage learning in various ways which usually do not exist in traditional classroom environments. Informal environments can meet the needs of students by offering different learning styles and allow each student to learn at their own pace (Melber \& Abraham, 1999). According to Crane, Nicholson, Chen and Bitgood (1994):

"Informal science learning refers to activities that occur outside the school setting, are not developed primarily for school use, are not developed to be part of an ongoing school curriculum, and are characterised as voluntary as opposed to mandatory participation as part of a credited school experience. (p. 3)

By nature, a child has a very high level of curiosity, therefore, the learning process should take into account their experiences and activities that can allow the children to explore and carry out their own research. This nature of curiosity is the reason why children ask so many "why" questions about a situation. They will continue questioning until they receive a satisfactory answer. This kind of attitude should not be restricted; it should be encouraged and developed to promote science literacy. Informal learning of science based on experience, inquiry, and hands-on activities are learning processes that can increase the science literacy (Fried Hoffer 2007), and enable them to learn from their environment. Children who are exposed with skills of science processes will indirectly have better thinking skills. Based on the existing knowledge and the new knowledge acquired in school, children are able to develop their own understanding and indirectly, active learning is taking place in their minds. Therefore, in order to help in increasing the number of people that enjoy and easily understand new information obtained through the rapid developments in science and technology, it is necessary to support formal education in schools with informal learning environments (Bozdogan \& Yalcin, 2009). Table 1 summarizes the differences between formal, non-formal and informal learning as follows:

Table 1. Comparison between formal, informal and non-formal learning

\begin{tabular}{llll}
\hline Characteristic & Formal & Non-formal & Informal \\
\hline Place/location & Usually at school & At institution out of school & Everywhere \\
Structure/Process & Maybe repressive, & Usually supportive, & Supportive, \\
& Structured, & Structured, & Unstructured, \\
& Usually prearranged, & Usually prearranged, & Spontaneous, \\
& Motivation is typically & Motivation may be extrinsic but it is & Motivation is mainly \\
& more extrinsic, & typically more intrinsic, & intrinsic, \\
& Compulsory, & Usually voluntary, & Voluntary, \\
& Teacher-led, & May be guided or teacher-led, & Usually learner-led, \\
& Sequential & Typically non-sequential & Non-sequential \\
& Learning is evaluated & Learning is usually not evaluated & Learning is not \\
& & & evaluated \\
\hline
\end{tabular}

Source: (Coombs, 1976; Eshach, 2006; Gerber, Marek \& Ann, 2001; Stocklmayer, Rennie \& Gilbert, 2010) 


\section{Non-Formal and Informal Science Learning in Malaysia}

Education has always been the chief vehicle for nation building in Malaysia. The 'mover' for education in Malaysia is under the responsibility of the Ministry of Education (MOE). The mission of the MOE of Malaysia is to "develop the potential of individuals through quality education". As Malaysia is now said to be at the mid-point in its journey towards Vision 2020, it is a necessity to prepare a more flexible workforce with advanced technical skills coupled with well-developed generic skills such as creative thinking, problem solving and analytical skills needed by the employer in the industry in order to survive in the challenging world. The Ministry is responsible for the overall education of Malaysian.

It is interesting to note that the MOE of Malaysia is actively supporting outdoor education. The Outdoor Education team was established within the Co-Curricular Activities Branch in 1991 in 6 states which are; Sabah, Sarawak, Kelantan, Pahang, Terengganu and Kedah (Md Amin, 2011). It provides assistance and guidance to the Malaysian schools in the planning and implementation of their outdoor education as a complement to the classroom learning. Besides that, the MOE also collaborates with the Ministry of Science, Technology and Innovation (MOSTI) in accordance to lead the informal and non-formal science education. The Second Science and Technology Policy provide the framework to enhance productivity and maintain growth and also strengthen the synergy partnership between government agencies, industries, universities, and research institutes. The role of MOSTI is in helping to achieve the aim of this policy in creating societal values and positive attitude towards science and technology including the need for lifelong learning. There are many agencies under MOSTI that operates to execute this aim.

The agencies under MOSTI that operate in order to introduce non-formal science education are Academy of Science and National Science Centre. Besides that, the most popular organizations that introduce non-formal education in Malaysia are Petrosains which operates under PETRONAS and National Planetarium which operates under the Prime Minister's Department. The role and function of each agency and centre which operate to introduce non-formal education in Malaysia are as follows:

Table 2. The agencies that promote non-formal learning in Malaysia

\begin{tabular}{ll}
\hline Bil & Institutional \\
\hline 1. & National Science Centre \\
& (http://www.psn.gov.my/en/concept-role/) \\
& and \\
& (Pusat Sains Negara, 2011)
\end{tabular}

\section{Role}

- The National Science Centre, an institution of non-formal learning, was entrusted with a mandate to promote awareness, interest and understanding of Science and Technology, to increase the knowledge of the Malaysian citizens.

- The exhibits located in National Science Centre are based on different themes which are divided into different categories.

- There are two main categories, Fundamental Science and Technology.

- The overall concept of the centre is to link science with the environment, religion, as well as to relate science with all aspects of life, knowledge and application in life.

2. Academy of Science (http://www.akademisains.gov.my/)

- Academy of Science is under the Ministry of Science, Technology and Innovation (MOSTI).

- Its mission is to pursue, encourage and enhance excellence in the field of science and technology, for the development of the nation and the benefit of mankind.

- The Academy of Science offer science engagement to students which covers; i) public awareness of science and technology; ii) nurturing interest in science, engineering and technology; iii) industry involvement; iv) engaging the public; and v) the creative culture. 
3. Petrosains

(http://www.petrosains.com.my/)

4. National Planetarium

(http://www2.angkasa.gov.my/planetarium )
- Petrosains operates under PETRONAS

- The Science Discovery Centre at Petrosains uses a fun and interactive approach to tell the story of the science and technology of the petroleum industry to the visitors.

- Its concept and contents revolve specifically around the science of petroleum, yet embrace all the general sciences.

- The hands-on approach adopted by Petrosains puts an emphasis on the fun and excitement of learning rather than on the rigorous memorization of scientific facts.

- National Planetarium plays a crucial role in promoting space science at large and leading Malaysia towards the development of space science.

Among the above-listed learning centres, there are still many agencies or organization that indirectly plays their role in the informal and non-formal science education in Malaysia. Among them are Malaysian Nature Society (MNS) and World Wild Life Fund (WWF) Malaysia, which handled outdoor program such as the Eco School (WWF-Malaysia, 2008, 2009). Besides that, in 2004, National Service Training Program, or Program Latihan Khidmat Negara (PLKN) was introduced by the Government of Malaysia as an outdoor education agent in order to empower and make a better youth in Malaysia (Jaffry, 2011).

\section{Discussion and Conclusion}

Education is the cornerstone of all efforts to produce skilled manpower. The education sector in Malaysia is changing dynamically, and is expected to undergo many changes in the $21^{\text {st }}$ century (Tuan Soh et al., 2012). Currently in Malaysia, as in many other parts of the world, students' attitudes towards science are far from positive and declining markedly as pupils progress through secondary school (International Association for the Evaluation of Educational Achievement (IEA), 2008, 2012; Lee \& Kamisah, 2013; Ministry of Education, 2012a, 2012b; Mohd Khaled, 2012; PISA, 2009). It seems that the formal education cannot achieve its goals in popularize science amongst the student, therefore informal and non-formal setting can be used in the effort of increasing students' awareness towards science.

According to Hofstein and Rosenfeld (1996), "future researches in science education should focus on how to effectively blend learning experiences in formal and informal learning in order to significantly enhance the learning of science" (p. 107). Therefore, it is a clear evidence that researchers agree that the integration of formal and informal setting can be used in order to increase the students' awareness towards science. This is because pupils of school age spend about two-thirds of their waking lives outside formal schooling (Eschah, 2006; Braund \& Reiss, 2006), therefore the influences that experiences outside school have on pupils' knowledge and understandings, beliefs, attitudes, and motivation to learn cannot be ignored (Braund \& Reiss, 2006). Science is indeed generally hard to learn. Yet, when pupils visit or taught in places that explain science in often new and exciting ways, they frequently seem to be more enthused. There is, we believe, something about these contexts and places that brings about a change in increasing the desire in people to find out and understand more (Braund \& Reiss, 2006).

Despite the advantages that can be gained through non-formal education, in reality, there is no synchronising at the national level for non-formal education programs. Every agency has their own method and programs according to their roles although the general aim is the same. Most of the non-formal educational programs are based on the needs of the respective agencies and once in a while, there will be overlapping of objectives. According to Townsend (1982), non-formal education should be an integral part of the education system of the country; it will be helpful for two separate systems of education to come into being. The recognition and various collaborations between the MOE and non-formal agencies should be planned in a more structured manner. The efforts to promote these institutions should be made in all schools; and encourage them to optimise the usage of these institutions as a complement to formal education in schools (Bozdogan \& Yalcin, 2009). An existing strategic network should be improved and strengthened. Besides that, a systematic mechanism should be created to coordinate the implementation and supervision of informal and non-formal science education effectiveness, in order to ensure that its role as a complement of formal education could be realized, and this changed climate will bring a new opportunity for formal and non-formal education to get closer together than ever before (Coombs, 1976) specifically in Malaysian context. 


\section{References}

Academy of Science. (2013). Mission/Vision. Retrieved June 3, 2013, from http://www.akademisains.gov.my/index.php?option=com_content\&task=view\&id=21\&Itemid=72

Anderson, D., Thomas, G. P., \& Ellenbogen, K. M. (2003). Learning Science from Experiences in Informal Contexts: The Next Generation of Research. Asia-Pacific Forum on Science Learning and Teaching, 4(1), $1-6$.

BERNAMA. (2012, February 29). Kemerosotan minat pelajar terhadap sains. Retrieved from http://www.utusan.com.my/utusan/info.asp?y=2012\&dt=0126\&pub=Utusan_Malaysia\&sec=Terkini\&pg=b t_21.htm

Best, S. (2007). Quaker events for young people: Informal education and faith transmission. Quaker Studies, 11, 259-281.

Bozdogan, A. E., \& Yalcin, N. (2009). Determining the Influence of a Science Exhibition Center Training Program on Elementary Pupils' Interest and Achievement in Science. Eurasia Journal of Mathematics, Science and Technology Education, 5(1), 27-34.

Braund, M., \& Reiss, M. (2006). Towards a More Authentic Science Curriculum: The contribution of out-of-school learning. International Journal of Science Education, 28(12), 1373-1388. http://dx.doi.org/10.1080/09500690500498419

Colletta, N. J., \& Holsinger, D. B. (1982). Assessing the Impact of Nonformal Education on Development Goals. Massachussets: Lexington Books Press.

Commonwealth Secretariat. (1979). Mobilizing Human Resources: Report of the Commonwealth Conference on Non-Formal Education for Development, New Delhi, 22 Jan-2 Feb 1979. London: Commonwealth Secretariat.

Coombs, P. H. (1976). Nonformal Education: Myths, Realities, and Opportunities. Comparative Education Review, 20(3), 281-293. http://dx.doi.org/10.1086/445902

Crane, V., Nicholson, H., Chen, M., \& Bitgood, S. (1994). Informal science learning: What Research about television, science museum, and community-based projects. Dedham, MA: Research Communications Ltd., and Ephrata, PA: Science Press.

Davies, K. (1997). The challenge of materials gallery: A new exhibition at the science museum. New Materials, 169-172.

Delamont, S. (2002). Fieldwork in Educational Settings: Methods, pitfalls and perspectives (2nd ed.). London and New York: Routledge: Taylor \& Francis Group.

Dib, C. Z. (1988). Formal, Non-Formal and Informal Education: Concepts/Applicability. In Interamerican Conference on Physics Education, Oaxtepec, Mexico, 1987 (pp. 300-315).

Eshach, H. (2006). Bridging In-school and Out-of-school Learning: Formal, Non-Formal, and Informal Education. Journal of Science Education and Technology, 16(2), 171-190. http://dx.doi.org/10.1007/s10956-006-9027-1

Fried Hoffer, B. (2007, 29 Nov-3 Dec). Why An Informal Science Intervention. Maxwell Auditorium, Singapore.

Gerber, B. L., Marek, E. A., \& Ann, M. L. (2001). Development of an informal learning opportunities assay. International Journal of Science Education, 23(6), 569-583.

Hannu, S. (1993). Science centre education: motivation and learning in informal education. Helsinki University Departmentof Teacher Education. Finland. Unpublished Doctoral Dissertation.

Hiong, L. C., \& Osman, K. (2013). An Interdisciplinary Approach for Biology, Technology, Engineering and Mathematics (BTEM) to Enhance 21st Century Skills in Malaysia. In Proceedings of the International Science, Mathematics and Technology Education Conference (ISMTEC) 2013 (pp. 1-11).

Hofstein, A., \& Rosenfeld, S. (1996). Bridging the Gap Between Formal and Informal Science Learning. Studies in Science Education, 28(1), 87-112. http://dx.doi.org/10.1080/03057269608560085

International Association for the Evaluation of Educational Achievement (IEA). (2008). TIMSS 2007 International Science (p. 512). TIMSS \& PIRLS International Study Center, Lynch School of Education: Boston College. 
International Association for the Evaluation of Educational Achievement (IEA). (2012). TIMSS 2011 International Science Report. Chestnust Hill: IEA.

Kelly, J. (2000). Rethinking the elementary science methods course: A case for content, pedagogy, and informal science education. Intenational Journal of Science Education, 22(7), 755-777. http://dx.doi.org/10.1080/09500690050044080

Kuenzi, J. J. (2008). Science, Technology, Engineering, and Mathematics (STEM). Education: Background, Federal Policy, and Legislative Action (pp. 1-34).

Martin, L. M. W. (2004). An emerging research framework for studying informal learning and schools. Science Education, 88(1), 71-82. http://dx.doi.org/10.1002/sce.20020

Md Amin Md Taff. (2011). Pendidikan Luar: Definisi, Falsafah \& Aplikasi (Md Amin Md Taff, Ed., 1st ed.). Tanjong Malim, Perak: Penerbit Universiti Pendidikan Sultan Idris.

Melber, L. H., \& Abraham, L. M. (1999). Beyond the classroom: Linking with informal education. Science Activities, 36, 3-4. http://dx.doi.org/10.1080/00368129909601027

Ministry of Education. (2012a). Laporan Strategi Mencapai Dasar 60:40 Aliran Sains/Teknikal: Sastera (p. 82). Putrajaya: KPM.

Ministry of Education. (2012b). Kajian TIMSS dan PISA: Status Pencapaian Malaysia [TIMSS and PISA Study: Malaysia Achievement Status].

National Planetarium. (2013). About Us; History. Retrieved June 3, 2013, from $\mathrm{http}: / /$ www2.angkasa.gov.my/planetarium/index.php?option $=$ com_content\&view=article \&id=7\&Itemid $=6$ \&lang=en

National Science Center. (2013). Concept and Role. Retrieved June 3, 2013, from http://www.psn.gov.my/en/concept-role/

Negara, P. S. (2011). Perjalanan 25 Tahun Pusat Sains Negara. Kuala Lumpur: Pusat Sains Negara.

Nordin, M. K. (2012, April 1). Persepsi negatif punca pelajar tidak minat sains. Berita Harian. Retrieved May 4, 2012, from http://www.bharian.com.my/bharian/articles/Persepsinegatifpuncapelajartidakminatsains/Article/index

Osman, K., Tuan Soh, T. M., \& Arsad, N. M. (2010). Development and validation of the Malaysian 21 st century skills instrument (M-21CSI) for science students. Procedia Social and Behavioral Sciences, 9, 599-603. http://dx.doi.org/10.1016/j.sbspro.2010.12.204

Pedretti, E. G. (2004). Perspectives on learning through research on critical issues-based science center exhibitions. Science Education, 88(Suppl. 1), 34-47. http://dx.doi.org/10.1002/sce.20019

Petrosains. (2013). About Us. Retrieved June 3, 2013, from http://www.petrosains.com.my/about-us/index.php

Phang, F. A., Abu, M. S., Ali, M. B., \& Salleh, S. (2012). Faktor Penyumbang Kepada Kemerosotan Penyertaan Pelajar dalam Aliran Sains: Satu Analisis Sorotan Tesis.

PISA. (2009). Assessment Framework: Key competencies in reading, mathematics and science. OECD 2009.

Stan, I. T. (2008). Group Interaction in the "Outdoor Classroom": The Process of Learning in Outdoor Education. Brunel University.

Stocklmayer, S. M., Rennie, L. J., \& Gilbert, J. K. (2010). The roles of the formal and informal sectors in the provision of effective science education. Studies in Science Education, 46(1), 1-44. http://dx.doi.org/10.1080/03057260903562284

Tight, M. (1996). Key Concepts in Adult Education and Training (2nd ed.). London \& New York: RoutledgeFalmer: Taylor \& Francis Group. http://dx.doi.org/10.4324/9780203434086

Townsend-Coles, E. (1982). Maverick of the Educational Family: Two Essays on Non-formal Education. Oxford: Pergamon Press.

Tuan Soh, T. M., Osman, K., \& Arsad, N. M. (2012). M-21CSI: A Validated $21^{\text {st }}$ Century Skills Instrument for Secondary Science Students. Asian Social Science, 8(16), 38-44. http://dx.doi.org/10.5539/ass.v8n16p38

WWF-Malaysia. (2008). Strengthening Environmental Education in existing National Curriculum. Malaysia. WWF-Malaysia. 
WWF-Malaysia. (2009). Environmental Citizenship: A Report On Emerging Perspectives in Malaysia. Malaysia. WWF-Malaysia.

Zakaria, J. (2011). Program Latihan Khidmat Negara (PLKN) sebagai agen Pendidikan Luar di Malaysia. In Md Amin Md Taff (Eds.), Pendidikan Luar: Definisi, Falsafah dan Aplikasi. Tanjong Malim, Perak: Penerbit Universiti Pendidikan Sultan Idris.

\section{Copyrights}

Copyright for this article is retained by the author(s), with first publication rights granted to the journal.

This is an open-access article distributed under the terms and conditions of the Creative Commons Attribution license (http://creativecommons.org/licenses/by/3.0/). 